\title{
The phlebological surgery in elderly patients
}

\author{
$\mathrm{G} \mathrm{Botta}^{1 *}, \mathrm{G}$ Baldoni ${ }^{1}, \mathrm{R}$ Serra${ }^{2}, \mathrm{~S}$ de Franciscis $^{2}$ \\ From de Senectute: Age and Health Forum \\ Catanzaro, Italy. 5-7 December 2009
}

The pathogenesis of the lower limbs varicose veins in the elderly patients is the same one as in the juvenile and adult age. What changes is the severity of the clinical picture, because the disease is a chronic pathology and it is aggravated with the passing of the years in absence of prophylaxis and missed or inadequate therapy.

Equally the surgical operations on the superficial venous system of the elderly patients from a technical point of view are the same that are practiced in other ages of life. What changes is the anaesthesiological risk, which is increased, because other chronic pathologies are frequently associated with the old ones.

Currently both the use of techniques of peripheral anesthesia, as the blocks of the lower limbs nervous trunks, and the introduction of poor toxic anesthetics for the heart in therapeutical practice allow in an incisive way to submit elderly people to surgical procedures.

Above all the out-patient hemodynamic surgery of the superficial chronic venous insufficiency, which requires a careful and meticulous instrumental investigation aimed surgical gestures, but simple, effective, of brief duration, has convinced many surgeons of the possibility to operate on the varicose patients of a more and more advance age.

On the other hand the rapid postoperative mobilization of those sick, in absence of immediate complications, means that they can be discharged from the hospital on the same day of the operation.

This undoubtedly involves positive reflexes on the sanitary expense and it increases at the same time the compliance in terms of motivation and acceptance of the proposed procedure.

The elderly patient, perhaps more than the younger adult, once informed of the new anaesthesiological and surgical techniques, gladly gives his consent to the intervention, pleased to return to his own house and tquickly return to his daily occupations.

${ }^{1}$ University of Siena, Department of Surgery, Center of Research, Therapy and Phlebolymphological Rehabilitatio, Italy
How much I dictate you is translated in our experience, that is carried out near the Phlebological Center of the Siena University, in a progressive increase in the last 5 years both in absolute terms (223) and percentages $(12 \%)$ of the number of subjects older than sixtyfive years old that have been submitted to surgical operations for the venous disease.

Of all 223 patients, males are 68 and females are 155; 144of them have an age between 66 and 70 years, 73 belonging to the eighty years of life and 6 subject to the ninty. All patients have been operated in Day Hospital admission. No mortality has been found. Local postoperative complications was encountered in $1,8 \%$ of the cases.

\section{Author details}

'University of Siena, Department of Surgery, Center of Research, Therapy and Phlebolymphological Rehabilitatio, Italy. ${ }^{2}$ University of Catanzaro, Department of Experimental and Clinical Medicine, Italy.

Published: 19 May 2010

doi:10.1186/1471-2318-10-S1-L6

Cite this article as: Botta et al:: The phlebological surgery in elderly patients. BMC Geriatrics 2010 10(Suppl 1):L6.

Submit your next manuscript to BioMed Central and take full advantage of:

- Convenient online submission

- Thorough peer review

- No space constraints or color figure charges

- Immediate publication on acceptance

- Inclusion in PubMed, CAS, Scopus and Google Scholar

- Research which is freely available for redistribution

Submit your manuscript at www.biomedcentral.com/submit
Ciomed Central 